\title{
3D Measurement of Surface Texture Parameters
}

Jan Podaný, Alexey Molotovnik

Faculty of Mechanical Engineering, Czech Technical University in Prague. Technická 4, 16607 Praha 6. Czech Republic. E-mail: Jan.Podany@fs.cvut.cz, Alexey.Molotovnik@fs.cvut.cz

The article focuses on the issue of 3D measuring surface parameters using optical measuring devices, designing a statistical experiment and following evaluation. The development non-contact surface texture measurement methods lead to new possibilities for describing the surface of machine parts. But cannot be to rely only on the obtained the measured parameters values, and it is true that it is necessary to prepare the measurement. The processes of measurement enter many influences. Some of these effects can manage it, and then we call those factors. At the output of the receive process feedback. Method DOE (Design of Experiments) is used to locate a combination of factors that provide the most favorable response. The proposal described experiment compares and evaluates various surface roughness parameters of two different materials and machining technologies samples. Measurements were done by two operators, and each measurement was carried out three times. Measurement took place on a confocal laser microscope LEXT OLS 3000.

Keywords: surface, measurement, DOE, roughness

\section{References}

[1] CSN EN ISO 4287. Geometrical product specifications (GPS) - Surface texture: Profile method - Terms, definitions and surface texture parameters, Praha: UNMZ, 1999. 24 p. Classifications 014450.

[2] ČSN EN ISO 25178-2. Geometrical product specifications (GPS) - Surface texture: Areal - Part 2: Terms, definitions and surface texture parameters, Praha: UNMZ, 2012. 52 p. Classifications 014451.

[3] ČSN EN ISO 25178-6. Geometrical product specifications (GPS) - Surface texture: Areal - Part 6: Classification of methods for measuring surface texture, Praha: UNMZ, 2010. 16 p. Classifications 014451.

[4] ASQ [online]. $8^{\text {th }}$ November 2013 [cit. 2013-11-8]. WWW: <http://asq.org/learn-about-quality/data-collection-analysis-tools/overview/design-of-experiments-tutorial.html>.

[5] ROUŠAR, M. (2010) Optical measurement of surface texture (in Czech), Praha: CTU in Prague. 101 p. Supervisor of thesis: Jan Podaný.

[6] DeVOR, R.E., CHANG, T., SUTHERLAND, J.W. (1992). Statistical Quality Design and Control, pp. 336-337 and 504-505. Prentice Hall, New Jersey.

[7] ROJEK, P., POKORNÝ, T., BARTOŠ J. (2014) 3D measurement of surface texture parameters (in Czech), Internal technical report. Supervisor: Jan Podaný.

[8] MATHIA, T. G., PAWLUS, P., WIECZOROWSKI, M. (2011) Recent trends in surface metrology, Wear, vol. 271, no. 3-4, pp. 494-508, 2011.

[9] H. ISHEIL-BUBAKER, J.F. FONTAINE, R. RAHEL, M.ROY, J. SERRI. (2013) 3D Displacements and Strains Solid Measurement based on the Surface Texture with a Scanner Laser, Procedia CIRP, Volume 12, Pages 468-473, ISSN 2212-8271, http://dx.doi.org/10.1016/j.procir.2013.09.080.

[10] LEGUTKO, S., KROLCZYK, G., KROLCZYK, J. (2014) Quality evaluation of surface layer in highly accurate Manufacturing, Manufacturing Technology, 14 (1), pp. 50-56.

[11] SHIH-WEI YANG, CHERN-SHENG LIN, SHIR-KUAN LIN, 3D surface profile measurement of unsymmetrical microstructure using Fizeau interferometric microscope, Optics and Lasers in Engineering, Volume 51, Issue 4, April 2013, pp. 348-357, ISSN 0143-8166, http://dx.doi.org/10.1016/j.optlaseng.2012.12.004.

[12] ČIERNA, H., ŤAVODOVÁ, M. (2013) Using the design of experiment method to evaluate quality of cuts after cutting aluminum alloy by AWJ, Manufacturing Technology, 13 (3), pp. 303-307.

[13] KROLCZYK, G., NIESLONY, P., LEGUTKO, S. (2014) Determination of tool life and research wear during duplex stainless steel turning, Archives of Civil and Mechanical Engineering. http://dx.doi.org/10.1016/j.acme.2014.05.001.

[14] KROLCZYK, G., LEGUTKO, S. (2014) Investigations into Surface Integrity in the Turning Process of Duplex Stainless Steel, Transactions of FAMENA, 38, 2, pp. $77-82$. 